\title{
SANITARY, PHYSIOLOGICAL QUALITY AND ALTERNATIVE TREATMENTS OF Dimorphandra gardneriana Tul. SEEDS
}

\author{
QUALIDADE SANITÁRIA, FISIOLÓGICA E TRATAMENTOS ALTERNATIVOS \\ DE SEMENTES DE Dimorphandra gardneriana Tul.
}

\author{
Flávio Ricardo da Silva CRUZ ${ }^{1}$; Rosemere dos Santos SILVA ${ }^{2}$; \\ Maria das Graças Rodrigues do NASCIMENTO ${ }^{2}$; Demetrius José da SILVA ${ }^{1}$; \\ Luciana Cordeiro do NASCIMENTO
}

1. Doutor em Agronomia, Programa de Pós-Graduação em Agronomia, Universidade Federal da Paraíba, Campus II, Areia, PB, Brasil. flricardocruz@ @otmail.com; 2. Mestra em Agronomia, Programa de Pós-Graduação em Agronomia, Universidade Federal da Paraíba, Areia, PB, Brasil. 3. Professora Associada da Universidade Federal da Paraíba, Campus II Areia, PB, Brasil.

\begin{abstract}
The Dimorphandra gardneriana Tul. species is widely distributed in the Brazilian territory presenting an economic and environmental importance. The aim of this study was to determine the fungi associated with Dimorphandra gardneriana seeds, assessing the influence of nystatin, the castor oil plant and Captan ${ }^{\circledR}$ fungicide in the control of these fungi in the seed germination and seedlings growth. The experiment was carried out at the Laboratório de Fitopatologia and Análise de Sementes of the Departamento de Fitotecnia e Ciências Ambientais of Centro de Ciências Agrárias of the Universidade Federal da Paraíba, Areia-PB, Brazil. Ten treatments were applied for mycoflora control: T1 - control (untreated seeds); T2 - nystatin (0.1\%); T3 - nystatin $(0.2 \%)$; T4 - nystatin $(0.3 \%)$; T5 - nystatin (0.4\%); T6 castor bean oil $(0.25 \%)$; T7 - castor bean oil $(0.5 \%)$; T8 - castor bean oil $(0.75 \%)$; T9 - castor bean oil $(1 \%)$; T10 fungicide Captan ${ }^{\circledR}$. For the evaluation of the effect of the treatments on the Dimorphandra gardneriana seeds the following variables were evaluated: germination, first counting of germination and germination speed index, percentage of abnormal seedlings, length and dry matter of shoots and roots of seedlings. Nystatin $(0.1 \%)$ reduced the incidence of Aspergillus sp. The Captan ${ }^{\circledR}$ fungicide reduced the incidence of fungi in the seeds and provided the best results for germination and vigor.
\end{abstract}

KEYWORDS: Germination. Forest species. Seed pathology. Alternative control.

\section{INTRODUCTION}

The fava-d'anta or faveira, as it is known the Dimorphandra gardneriana Tul., (FILIZOLA, 2013) belongs to the Fabaceae family and occurs in the Brazilian states of Maranhão, Piauí, Ceará, Pernambuco, Bahia, Pará, Goiás, Mato Grosso and Minas Gerais (MONTANO et al., 2007). The species is mainly used for medicinal purposes, the fruits contains a large quantity of secondary compounds, among them rutin (quercetin-3rutinosidium), which is a glycoside flavonoid used in popular medicine and generally indicated as a vasoprotectant, and causes an increase in the resistance of blood capillaries (FERES et al., 2010). This compound is widely explored by the pharmaceutical and cosmetic industry and is considered one of the most promising substances for the production of drugs that helps to combat aging and degenerative diseases (GONÇALVES et al., 2010).

The fava-d'anta (Dimorphandra gardneriana), besides having a great potential for exploitation due to the presence of compounds valued by the pharmaceutical industry, has also a great environmental importance, being indicated for the recovery of degraded areas, especially those where this species populations has been increasingly reduced (LANDIM; COSTA, 2012). In Brazil, because of the absence of cultivated areas of this species, it is exploited by disorganized extraction and, in the long term, in a depredating way, since it has no genetic basis for its conservation, which directly reflects on the reproductive success and natural regeneration of the species (FILIZOLA, 2013). In addition, there is a lack of concern with the propagation, as well as absence of knowledge in good practices for the conservation of this resource, since the procedure used during the collection damage severely the parent plants (PAULA et al., 2007; NUNES et al., 2012).

Seeds of forest species are the basic input in the production of seedlings that will be used in reforestation programs, recovery of degraded areas, urban afforestation and preservation of endangered species. Seed manipulation requires a specific care, since its quality is influenced by a number of factors (MEDEIROS et al., 2012), such as plant pathogenic microorganisms like fungi. These microorganisms are responsible for the formation of seedlings with 
abnormalities and lesions, as well as the deterioration of structures essential for the formation of seedlings and, consequently, healthy trees (VECHIATO; PARISI, 2013).

The control of fungi through treatment of chemical products is a subject well explored in the researches of seed sanity. However, it is important to note that the use of these fungicides may contribute to the contamination of the environment with toxic residues and increase the resistance of microorganisms (OLIVEIRA et al., 2011). Thus, there is a need to investigate other methods of controlling pathogens in seeds and, in this sense, some techniques based on the use of plant extracts appear as a good alternative to synthetic fungicides. The use of plants in the form of extract or essential oils is gaining space in the protection of grain and seeds against pathogens. These products consist of an environmentally friendly alternative, less pollutant, easy to be acquired and at a lower cost (BOFF and ALMEIDA, 2005); however, their fungitoxic activity should not cause germination damage. Good results of the use of essential oils on mycoflora reduction were obtained with the use of copaiba oil (Copaifera multijuga Hayne) (DEUS et al., 2011), castor bean oil (Ricinus communis L.) (SORATO et al., 2016), among others.

In this context, the present study aimed to verify which fungi are associated with Dimorphandra gardneriana seeds, evaluating the influence of nystatin, castor bean oil and the fungicide Captan ${ }^{\circledR}$ on the sanitary quality, seed germination and seedling growth of the previous mentioned species.

\section{MATERIAL AND METHODS}

\section{Location of collection and conduction of the experiment}

The experiment was carried out at the Laboratórios de Fitopatologia e Análise de Sementes of the Departamento de Fitotecnia e Ciências Ambientais of the Centro de Ciências Agrárias, Universidade Federal da Paraíba, Areia PB. The seeds of Dimorphandra gardneriana were obtained from fruits of fifteen parent trees located in the municipalities of Crato and Jardim, state of Ceará, in September of 2013. After the fruit processing to obtain the seeds, they were sent to the Laboratório de Análise de Sementes where they were stored in plastic bags and placed in a cold room with average temperature and humidity of 17 ${ }^{\circ} \mathrm{C}$ and $60 \%$, respectively, until the start of the experiment in May 2014.

\section{Treatment of the seeds}

Before the composition of the treatments, the seeds were homogenized and had their tegument ruptured on the opposite side of the hilum (URSULINO et al., 2016), using a nail clipper, in order to overcome integument dormancy and were then disinfested with a solution of $1 \%$ sodium hypochlorite for three minutes. Subsequently, the seeds were submitted to the following treatments: $\mathrm{T} 1$ - control (untreated seeds); T2 - nystatin (0.1\%); T3 - nystatin (0.2\%); T4 - nystatin $(0.3 \%)$; T5 nystatin $(0.4 \%)$; T6 castor bean oil $(0.25 \%)$; T7 castor bean oil $(0.5 \%)$; T8 castor bean oil $(0.75 \%)$; T9 castor bean oil (1.0\%); T10 - Captan ${ }^{\circledR}$ fungicide at a concentration of $240 \mathrm{~g}$ of the product for $100 \mathrm{~kg}$ of seeds. Pure $(100 \%)$ castor bean oil of the brand Farmax was used and, for the preparation of the solutions, quantities of this oil were emulsified with Tween 80 and then sterile distilled water (SDW) was added to obtain the previous mentioned concentrations. Pre-established concentrations with nystatin were obtained from the dilution of the product with SDW. After the seeds were immersed in the treatments for three minutes, they were incubated in Petri dishes on a double layer of filter paper sterilized and moistened with SDW.

\section{Sanitary test}

One hundred seeds were used for each treatment, distributed in 10 replications. The petri dishes were kept for 7 days at a temperature of $25 \pm$ $2{ }^{\circ} \mathrm{C}$ and after this period the fungi were identified by using optical and stereoscopic microscopes, and specialized literature (MENEZES and OLIVEIRA, 1993). The results were expressed as percentage of incidence.

Physiological quality test - For this test were evaluated:

Germination test - One hundred seeds were divided in four replications of 25 and distributed over a doubled layer of germination paper, covered with a third sheet and arranged in the form of rollers. The paper was moistened with an amount of SDW equivalent to 2.5 times its dry weight and then distributed in a germinating chamber of the Biochemical Oxygen Demand (B.O.D) type regulated at the alternating temperature of $20-30{ }^{\circ} \mathrm{C}$ and photoperiod of eight hours (unpublished data). After seeding, the rolls were packed in transparent plastic bags in order to keep the humidity. The counts were performed daily from the fifith to the fourteenth day, considering the normal seedlings, those with characteristics prescribed by the Rules for Seed Analysis (RSA) (BRASIL, 2009). The 
percentage of abnormal seedlings was determined at the end of the test (BRASIL, 2009).

First counting of germination - Concurrently carried out with the germination test, being counted the germinated seeds after the fifth day after seeding. The obtained data were expressed as percentage.

Germination speed index - Concurrently carried out with the germination test where were daily counted the germinated seeds until stabilization (Fourteenth day). The index was determined according to the formula proposed by Maguire (1962).

Length and dry matter of the seedlings - The aerial part and the primary root of all normal seedlings were measured with a graduated ruler in centimeters and the results were expressed in centimeters, at the end of the germination test. After the measurement, the shoots and roots of the seedlings from the previous evaluations were placed separately in paper Kraft bags and taken to the stove at $65{ }^{\circ} \mathrm{C}$ for 48 hours. After this period, they were weighed in an analytical scale at an accuracy of $0.001 \mathrm{~g}$, the results were expressed in grams.

For both, the sanitary and the physiological quality test evaluations, a completely randomized design (DIC) was used. The data were submitted to analysis of variance by the $F$ test $(p \leq 0.05)$ and the means were compared by the Scott-Knott test at $5 \%$ of probability using the software SISVAR $^{\circledR}$ (FERREIRA, 2007).

\section{RESULTS AND DISCUSSION}

The following values for the percentage of fungi incidence were observed on the not treated seeds of Dimorphandra gardneriana: Aspergillus niger van Tieghem (47\%), Aspergillus sp. (20\%), Penicillium sp. (12\%), Rhizopus sp. (4\%) Botrytis sp. (3\%), Periconia sp. (2\%) and Fusarium sp. (3\%). There are few citations of Cladosporium sp. incidence on seeds of forest species (ARAUJO et al., 2009), with records of their occurrence in seeds of species such as amendoim bravo (Pterogyne nitens Tul.) (NASCIMENTO et al., 2006), acácianegra (Acacia mearnsii De Wild.) (SANTOS et al., 2001) and pata-de-vaca (Bauhinia variegata L.) (MARTINELLI-SENEME et al., 2006).

After the application of the treatments on Dimorphandra gardneriana seeds, the presence of Cladosporium sp. and Curvularia sp. was observed, which did not occur in the untreated (control) seeds, both with incidence lower than $7 \%$. There was no significant effect of the treatments on the incidence of these fungi, as well as on the occurrence of Botrytis sp. Periconia sp. and Fusarium sp., which justifies their absence in Figure 1.

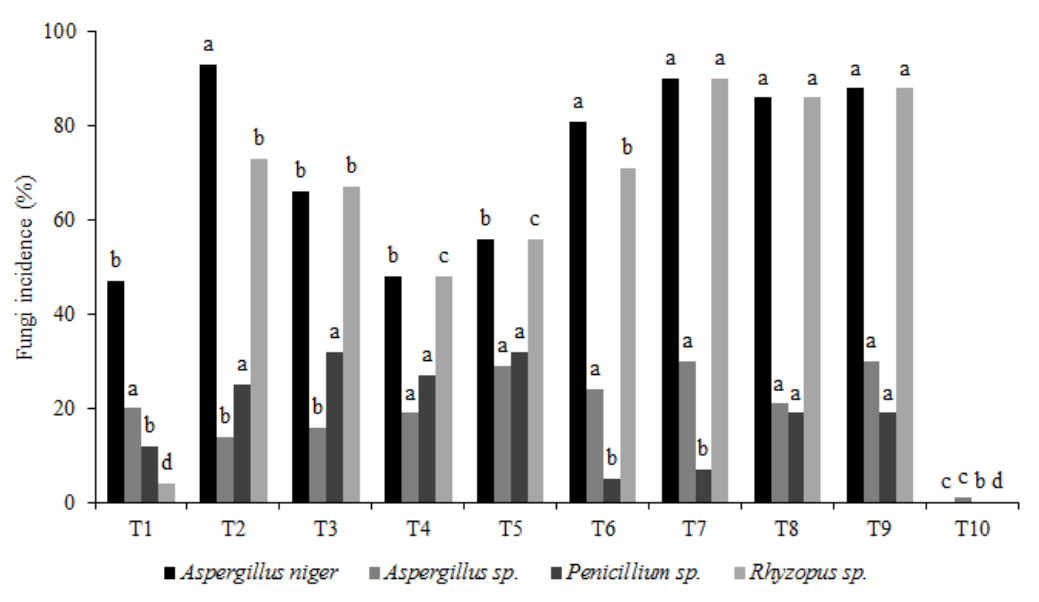

Figure 1. Fungi incidence in Dimorphandra gardneriana seeds under the treatments: T1 - control; T2 - nystatin $(0.1 \%)$; T3 - nystatin $(0.2 \%)$; T4 - nystatin $(0.3 \%)$; T5 - nystatin $(0.4 \%)$; T6 - castor bean oil $(0.25 \%)$; T7 - castor bean oil $(0.5 \%)$; T8 - castor bean oil $(0.75 \%)$; T9 - castor bean oil (1\%); T10 - fungicide Captan $^{\circledR}$. Means with the same letter do not differ by the Scott-Knott test at $5 \%$ of probability.

For the genus Cladosporium, its presence was observed in all of the treatments with nystatin and castor bean oil, except for the treatments T5 nystatin (0.4\%) and T9 - castor bean oil (1\%). The Curvularia sp. was observed only in the treatment
T6 - castor bean oil $(0.25 \%)$. The fungi Aspergillus niger and Rhizopus sp. had their incidence increased compared to the control when the seeds of Dimorphandra gardneriana were treated with nystatin and castor bean oil. This probably occurred 
because these treatments potentiated the proliferation of these fungi. According to the concentration of the compounds, synergism relationships may occur in the essential oils, promoting the induction of growth of the microorganisms (MAIRESSE, 2005).

Some of the previously mentioned fungi, such as Aspergillus niger, Fusarium sp. Penicillium sp. and Rhizopus sp. were also observed by Medeiros et al. (2013b) on sombreiro seeds (Clitoria fairchildiana R.A.Howard). Seven species of fungi were detected in amendoim bravo (Pterogyne nitens) seeds, among them Aspergillus sp. and Penicillium sp. had the highest percentage of occurrence compared to the others (NASCIMENTO et al., 2006). Giuliano et al. (2005) found that favad'anta seeds (Dimorphandra mollis Benth.) have microorganisms that can negatively influence their germination and even cause their death. The same authors verified the occurrence of Absidia corymbifera (Cohn) Sacc \& Trotter (1.0\%), Curvularia pallescens Boedjin (3,0\%), Aspergillus niger $(1,8 \%)$ and Aspergillus sp. (2.0\%).

No significant effect were found for the treatments on the fungi Botrytis sp., Periconia sp. and Fusarium sp. The treatments $\mathrm{T} 2$ - nystatin $(0.1 \%)$ and $\mathrm{T} 3$ - nystatin $(0.2 \%)$ decreased the incidence of Aspergillus sp. The action of nystatin is due to its binding and alteration of the fungal cells wall sensitive to it, causing its destruction (Figure 1). All treatments, with the exception of T10 Captan $^{\circledR}$ fungicide, significantly increased the incidence of Penicillium sp. compared to the control, the treatments T6 - castor bean oil $(0.25 \%)$ and T7 - castor bean oil $(0.5 \%)$ caused a reduction, although not significant.

The antifungal action of the essential oils is related to their interaction with the lipids of the cell wall, cell membrane and fungi mitochondria, interfering on the permeability, causing disturbances in their structures (COSTA et al., 2011). The use of essential oils extracted from plants to inhibit plant pathogenic fungi is one of the alternatives to minimize the negative effects of the use of agrochemicals on seeds. This solution has been well seen due to the current worldwide interest in the use of products that are less aggressive to the environment (ZANANDREA et al., 2004; SOUSA et al., 2012). Mata et al. (2009) evaluated the action of citronella oil (Cymbopogon winterianus Jowitt.) and anise plant (Pimpinella anisum L.) on the control of fungi on mandacaru (Cereus jamacaru DC.) seeds, and observed the efficiency of the anise plant essential oil in the control of the fungi Cladosporium sp., Curvularia sp. Nigrospora sp. and citronella oil on Cladosporium sp. and Nigrospora sp.

The fungicide Captan $^{\circledR}$ inhibited the occurrence of all fungi observed in the control and the other treatments, except for Aspergillus sp., which incidence was only $1 \%$. Good results were also obtained by Medeiros et al. (2013a), where they found that the fungicide Captan $^{\circledR}$ eradicated the fungi detected in the seeds of amendoim bravo (Pterogyne nitens). Silva et al. (2011) evaluating the effect of chemical treatments on the sanitary quality of seeds of forest species, verified that the fungicides Captan $^{\circledR}$ and Tiram $^{\circledR}$ reduced the incidence of the fungi genus observed in comparison to the control. There was a significant increase of Aspergillus niger in the treatments T2 nystatin $(0.1 \%)$ and in all treatments with the castor bean oil. The incidence of Rhizopus sp. increased significantly in all treatments with the use of nystatin and castor bean oil, except for the treatments T6 - castor bean oil $(0.25 \%)$ and T10 fungicide $\operatorname{Captan}^{\circledR}$. The total elimination of certain fungi detected in the seeds may depend on factors such as: their location in the seed, the physiological conditions of the seeds, as well as the concentration and the period of immersion in the chemicals used in the asepsis (SOUSA et al., 2012).

The germination of Dimorphandra gardneriana seeds was negatively affected by the presence of fungi associated to them. In Figure 2A it is possible to observe that the fungicide Captan $^{\circledR}$ promoted the highest percentage of seed germination of the species, reflecting its efficiency in the control of fungi. In the T8 treatment, castor bean oil favored the increase of abnormal seedlings and non-germinated seeds, which culminated in the absence of seedlings at the end of the test. For the first counting of germination, differences between the means were observed, with the highest values obtained in the treatments T4 - nystatin $(0.3 \%)$, T5 nystatin $(0.4 \%)$ and T10 - fungicide Captan ${ }^{\circledR}$ (Figure 2A). There was no significant effect observed by the F test for the germination speed index of the treated and untreated (control) seeds of Dimorphandra gardneriana. Nascimento et al. (2006) verified that the fungi associated with amendoim bravo seeds (Pterogyne nitens) did not affect the germination due to the low incidence in the evaluated lots. Lazarotto et al. (2013) when evaluating the quality of cedar tree (Cedrela fissilis Vell.) from different places, found that the garlic extract (Allium sativum L.) was as efficient as the physical treatment (dry heat at $70 \pm 3{ }^{\circ} \mathrm{C}$ per 48 hours) and the chemical (fungicide $\operatorname{Captan}^{\circledR}$ ) in the control of microorganisms, favoring the germination of their 
seeds. Leite et al. (2012) verified that the alamanda extract (Allamanda blanchetti A.DC.), used as a phytosanitary treatment in seeds of Mimosa caesalpiniifolia Benth. did not inhibit the germination, observing the highest value in the first counting.

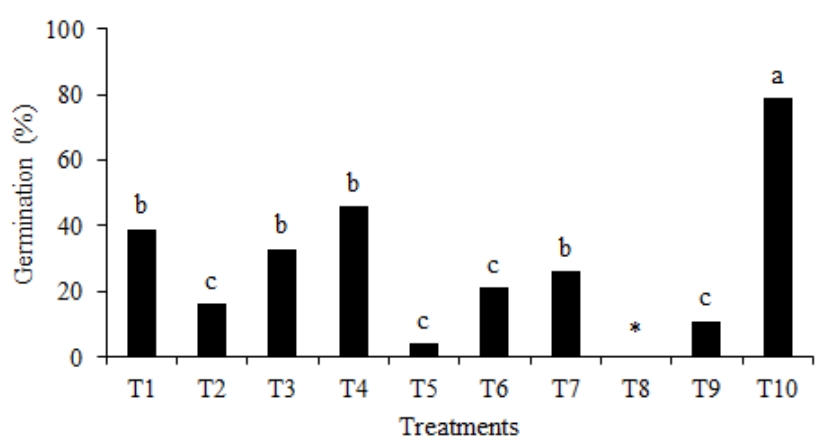

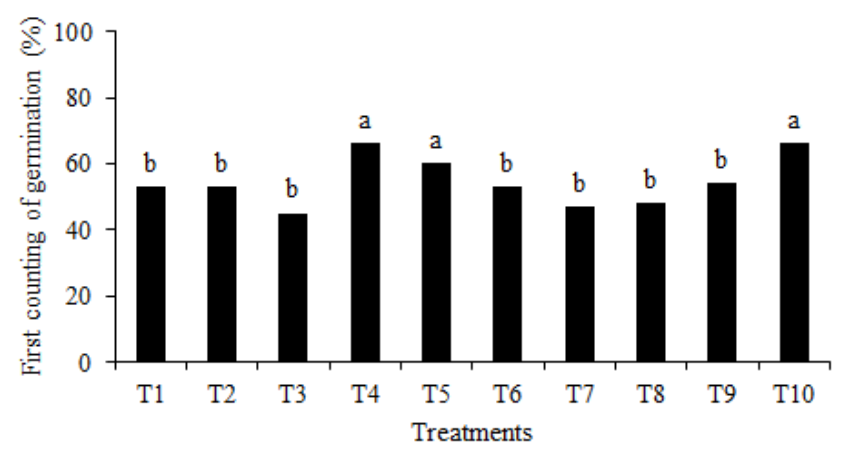

Figure 2. Percentage of germination (A) and first counting of germination (B) of Dimorphandra gardneriana seeds under the treatments: T1 - control; T2 - nystatin $(0.1 \%)$; T3 - nystatin $(0.2 \%)$; T4 - nystatin $(0.3 \%)$; T5 - nystatin $(0.4 \%)$; T6 - castor bean oil $(0.25 \%)$; T7 - castor bean oil $(0.5 \%)$; T8 - castor bean oil $(0.75 \%)$; T9 - castor bean oil (1\%); T10 - fungicide Captan ${ }^{\circledR} . *$ No plants to evaluate. Means with the same letter do not differ by the Scott Knott test at $5 \%$ of probability.

The highest percentages of abnormal seedlings were observed in the treatments $\mathrm{T} 2$ nystatin $(0.1 \%)$, T3 - nystatin $(0.2 \%)$, T5 - nystatin $(0.4 \%)$, T8 - castor oil $(0,75 \%)$ and $\mathrm{T} 9$ - castor bean oil $(1 \%)$, where the mean values did not differ statistically from each other (Figure 3). Although the T5 treatment did not influence negatively the first counting of germination, at the end of the test a high percentage of abnormal seedlings were verified. There is lack of information regarding the use of nystatin in treatment against plant pathogens, however, it has been used in water for substrate watering in the control of fungi of forest species, as such in yellow api (Tabebuia serratifolia (Vahl) G.Nichols.) (SOUZA et al., 2005), trapiá (Crataeva tapia L.) (GALINDO et al., 2012) and quixabeira (Sideroxylon obtusifolium (Roem. \& Schult.) T.D.Penn. both at the concentration of $0,2 \%$ (REBOUÇAS et al., 2012). Netto and Faiad (1995) emphasized that the sanitary quality of the seeds are very important, because the microorganisms present in the seeds can cause their deterioration, as well as abnormalities and lesions in the seedlings.

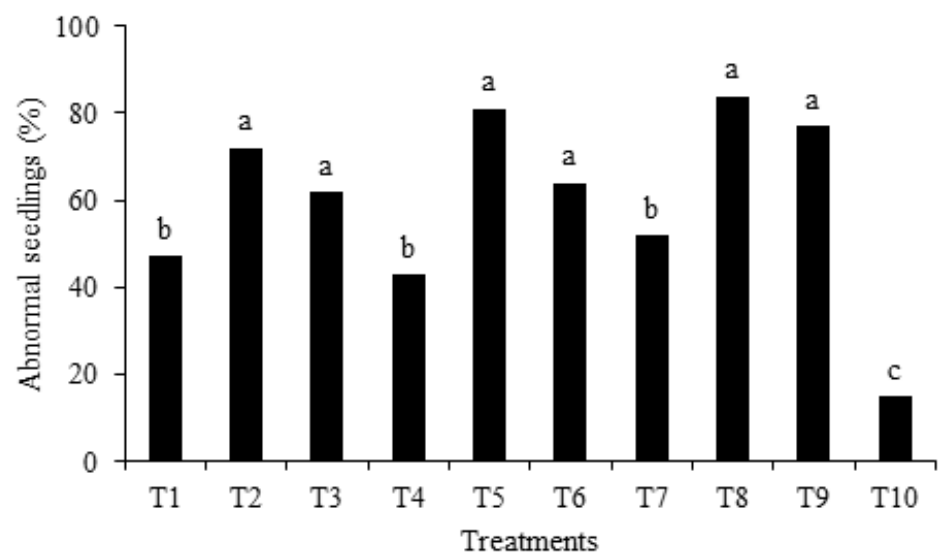

Figure 3. Percentage of abnormal seedlings of Dimorphandra gardneriana under the treatments: T1 - control; $\mathrm{T} 2$ - nystatin $(0.1 \%)$; T3 - nystatin $(0.2 \%)$; T4 - nystatin $(0.3 \%)$; T5 - nystatin $(0.4 \%)$; T6 - castor bean oil ( $0.25 \%)$; T7 - castor bean oil $(0.5 \%)$; T8 - castor bean oil $(0.75 \%)$; T9 - castor bean oil $(1 \%)$; T10 - fungicide Captan ${ }^{\circledR}$. Means with the same letter do not differ by the Scott-Knott test at $5 \%$ of probability. 
It is possible to observe in the Figure 4 that the highest values for root and shoot length were verified in the treatment $\mathrm{T} 10$ - Captan $^{\circledR}$ fungicide compared to the other treatments evaluated. Differently from some experiments with essential oils, the treatment with castor bean oil was not efficient in most of the used concentrations. Some essential oils did not worked as direct inhibitors of fungi, which means that they do not have fungitoxic effect for some species (RODRIGUES; CHILDERS, 2002). In addition, it should be noted that the essential oils have active principles which, although are natural, they are chemical substances and must be used with discretion, especially in seeds (DARONCO, 2013).

Different results on treatment with essential oil of eucalyptus (Eucalyptus grandis Hill ex
Maiden) were found where it provided a greater seed germination and development of roots and shoots of eucalyptus seedlings (STEFFEN et al., 2010). Studies with citronella (Cymbopogon nardus (L.) Rendle), eucalyptus (Eucalyptus citriodora Hook.) and citronellal compounds proved that they strongly inhibited the fungi associated with maize (Zea mays L.) seeds (BRITO et al. Al., 2012). Lobato et al. (2007) obtained, trough assays, positive responses of the activity of the pimento-demacaco (Piper aduncum L.) at 0,5; 1.0; 4.0; 8.0\%, reducing the incidence of fungi from $86 \%$ to $16 \%$ in cowpea bean seeds [Vigna unguiculata (L.) Walp .]. Takano et al. (2007) concluded that castor bean oil (Ricinus communis L.) suppressed the mycelial growth of Pyricularia grisea (Cooke) Sacc in 100\% at the concentration of $200 \mathrm{ml} \mathrm{l}^{-1}$.
A

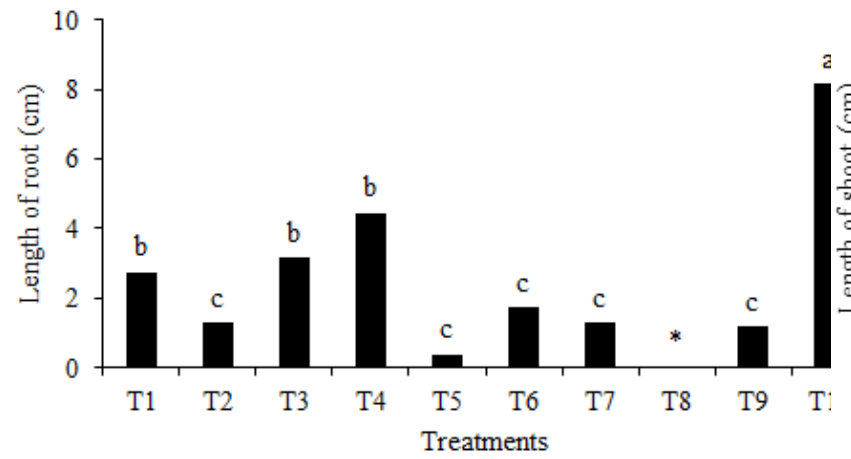

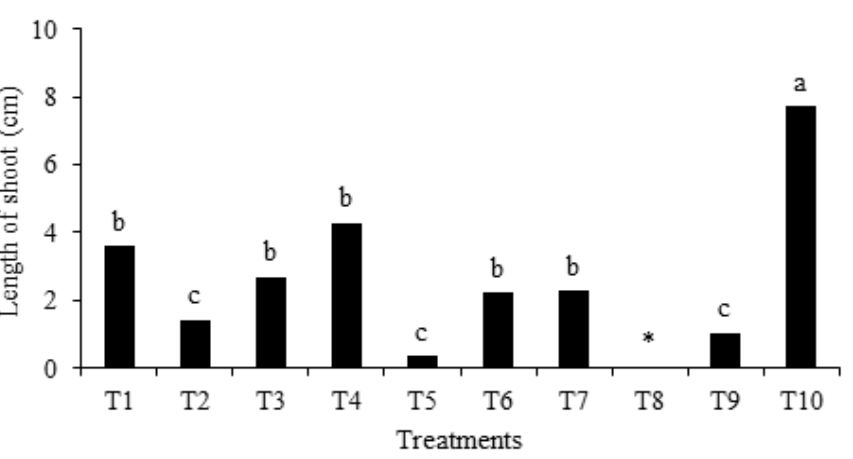

Figure 4. Length of root (A) and shoot (B) of Dimorphandra gardneriana seedlings from seeds under the treatments: $\mathrm{T} 1$ - control; $\mathrm{T} 2$ - nystatin $(0.1 \%)$; T3 - nystatin $(0.2 \%)$; $\mathrm{T} 4$ - nystatin $(0.3 \%)$; $\mathrm{T} 5$ nystatin $(0.4 \%)$; T6 - castor bean oil $(0.25 \%)$; T7 - castor bean oil $(0.5 \%)$; T8 - castor bean oil $(0.75 \%)$; T9 - castor bean oil (1\%); T10 - fungicide Captan ${ }^{\circledR} . *$ No plants to evaluate. Means with the same letter do not differ by the Scott-Knott test at $5 \%$ of probability.

The results obtained in the evaluation of the root and shoot dry matter also reinforced the superiority of the fungicide Captan ${ }^{\circledR}$ in the control of fungi associated with the seeds of Dimorphandra gardneriana (Figure 5). Similar to what was observed in the shoot length, the castor bean oil was not adequate to control fungi in the seeds of this species, which was verified in the low values for shoot dry matter in all concentrations evaluated.

For Mondego et al. (2014) embiratanha seeds [Pseudobombax marginatum (A.St.-Hil., Juss. \& Cambess.) A.Robyns] treated with essential oil of copaíba (Copaifera sp.) at $1 \%$ of concentration presented the highest means for the variables dry matter of roots $(0.0063 \mathrm{~g})$ and shoots $(0.035 \mathrm{~g})$. According to these authors, the treatment with
Captan ${ }^{\circledR}$ fungicide was inferior to the essential oil of copaiba at $1 \%$ in the two analyzed variables, different from the result observed in Dimorphandra gardneriana seedlings. The chemical treatment, although presenting higher cost and environmental damage, has been widely used because of its efficiency in the control of seed pathogens (CAMPANHOLA; BETTIOL, 2003). The control of plant pathogens using natural treatments, especially with essential oils, in seeds of forest species is still not well studied. Natural products offer a low-cost alternative to producers, besides the reduction of environmental impacts generated by commercial agrochemicals (COUTINHO et al., 1999). 

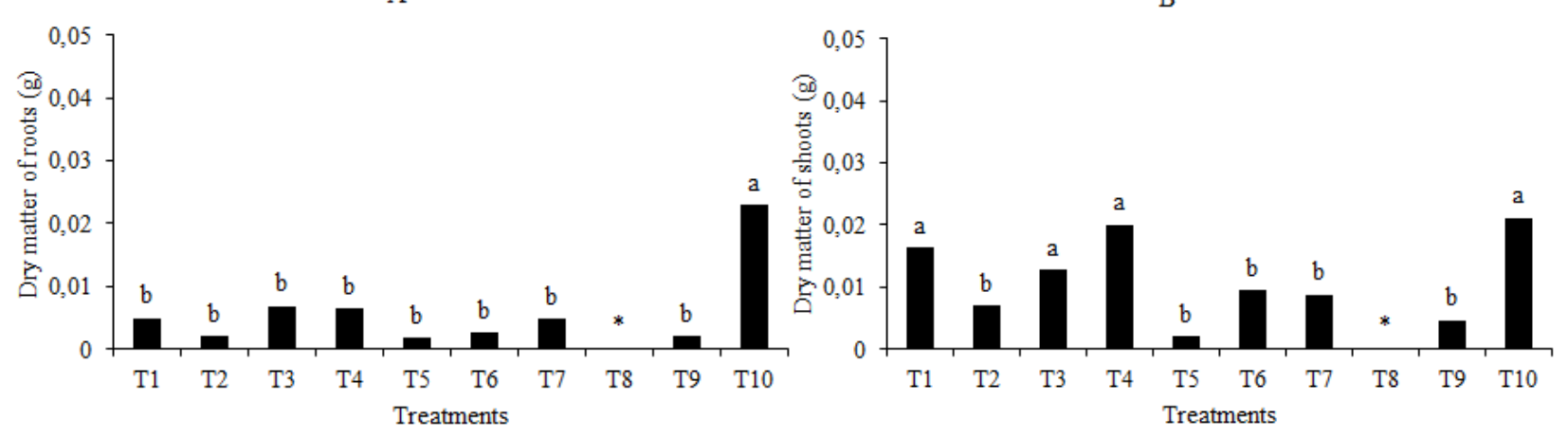

Figure 5. Dry matter of roots (A) and shoots (B) of Dimorphandra gardneriana seedlings from seeds under the treatments: T1 - control; T2 - nystatin $(0.1 \%)$; T3 - nystatin $(0.2 \%)$; T4 - nystatin $(0.3 \%)$; T5 nystatin $(0.4 \%)$; T6 - castor bean oil $(0.25 \%)$; T7 - castor bean oil $(0.5 \%)$; T8 - castor bean oil $(0.75 \%)$; T9 - castor bean oil (1\%); T10 - fungicide Captan ${ }^{\circledR}$.* No plants to evaluate. Means with the same letter do not differ by the Scott-Knott test at $5 \%$ of probability.

\section{CONCLUSIONS}

The Fungicide Captan $^{\circledR}$ can be used in the control of fungi on Dimorphandra gardneriana seeds;
The nystatin is more efficient on the preservation of the physiological quality of the seeds of this species compared to the castor bean essential oil.

RESUMO: A espécie Dimorphandra gardneriana Tul. tem ampla distribuição no território brasileiro, apresentando importância econômica e ambiental. O objetivo desse trabalho foi verificar quais fungos estão associados a sementes de Dimorphandra gardneriana, avaliando a influência da nistatina, do óleo de rícino e do fungicida Captan ${ }^{\circledR}$, no controle desses fungos, na germinação de sementes e no crescimento de plântulas. O experimento foi realizado nos Laboratórios de Fitopatologia e de Análise de Sementes do Departamento de Fitotecnia e Ciências Ambientais do Centro de Ciências Agrárias da Universidade Federal da Paraíba, Areia-PB, Brasil. No controle da micoflora foram aplicados 10 tratamentos, a saber: T1 - testemunha (sementes não tratadas); T2 - nistatina $(0,1 \%)$; T3 - nistatina $(0,2 \%)$; T4 - nistatina $(0,3 \%)$; T5 - nistatina $(0,4 \%)$; T6 - óleo de rícino $(0,25 \%)$; T7 - óleo de rícino $(0,5 \%)$; T8 - óleo de rícino $(0,75 \%)$; T9 óleo de rícino (1\%); T10 - fungicida Captan ${ }^{\circledR}$. Para avaliar o efeito dos tratamentos sobre as sementes de Dimorphandra gardneriana foram avaliadas as variáveis: germinação, primeira contagem de germinação e índice de velocidade de germinação, porcentagem de plântulas anormais, comprimento e massa seca da parte aérea e de raízes de plântulas. A nistatina $(0,1 \%)$ diminuiu a incidência de Aspergillus sp. O fungicida Captan ${ }^{\circledR}$ reduziu a incidência de fungos nas sementes da espécie e proporcionou os melhores resultados para germinação e vigor.

PALAVRAS-CHAVE: Germinação. Espécies florestais. Patologia de sementes. Controle alternativo.

\section{REFERENCES}

ARAUJO, A. V.; SALES, N. L. P.; FERREIRA, I. C. P. V.; BRANDÃO JUNIOR, D.; MARTINS, E. R. Germinação, vigor e sanidade de sementes de fava d'anta (Dimorphandra mollis Benth.) obtidas de frutos coletados no solo e na planta. Revista Brasileira de Plantas Medicinais, Botucatu, v. 11, n. 2, p. 170-175, 2009. http://dx.doi.org/10.1590/S1516-05722009000200010

BOFF, M. I. C.; ALMEIDA, A. A. Atividade inseticida de extratos de pimenta-do-reino, Piper nigrum (Piperaceae) sobre a progênie da traça-dos-cereais, Sitotroga cerealella (Lepidóptera: Gelechiidae). Revista Brasileira de Armazenamento, Viçosa, v. 30, n. 2, p. 111-116, 2005.

BRASIL. Ministério da Agricultura, Pecuária e Abastecimento. Regras para análise de sementes. Secretaria Nacional de Defesa Agropecuária. Brasília: MAPA/ACS, 2009. 395 p. 
BRITO, D. R.; OOTANI, M. A.; RAMOS, A. C. C.; SERTÃO, W. C.; AGUIAR, R. W. S. Efeito dos óleos de citronela, eucalipto e composto citronelal sobre micoflora e desenvolvimento de plantas de milho. Journal of Biotechnology and Biodiversity, Palmas, v. 3, n. 4, p. 184-192, 2012.

https://sistemas.uft.edu.br/periodicos/index.php/JBB/article/download/402/280/

CAMPANHOLA, C.; BETTIOL, W. Panorama sobre o uso de agrotóxicos no Brasil. In: CAMPANHOLA, C.; BETTIOL, W. Métodos alternativos de controle fitossanitário. Jaguariúna: Embrapa Meio Ambiente, 2003. p. 13-50.

COSTA, A. R. T.; AMARAL, M. F. Z. J.; MARTINS, P. M.; PAULA, J. A. M.; FIUZA, T. S.; TRESVENZOL, L. M. F.; PAULA, J. R.; BARA, M. T. F. Ação do óleo essencial de Syzygium aromaticum (L.) Merr. \& L. M. Perry sobre as hifas de alguns fungos fitopatogênicos. Revista Brasileira de Plantas Medicinais, Botucatu, v. 13, n. 2, p. 240-245, 2011. http://dx.doi.org/10.1590/S1516-05722011000200018

COUTINHO, W. M.; ARAÚJO, E.; MAGALHÃES, F. H. L. Efeitos de extratos de plantas anacardiáceas e dos fungicidas químicos benomyl e captan sobre a micoflora e qualidade fisiológica de sementes de feijoeiro (Phaseolus vulgaris L.). Ciência e Agrotecnologia, Lavras, v. 23, n. 3, p. 560-568, 1999. http://www.editora.ufla.br/index.php/component/phocadownload/category/33-volume-23-numero3?download=440: vol23numero3.

DARONCO, M. V. Óleos essenciais no tratamento de sementes de soja (Glycine max L.). 2013. 49 f. Monografia (Graduação em Agronomia) - Universidade Regional do Noroeste do Estado do Rio Grande do Sul, Ijuí, 2013.

DEUS, R. J. A.; ALVES, C. N.; ARRUDA, M. S. P. Avaliação do efeito antifúngico do óleo resina e do óleo essencial de copaíba (Copaifera multijuga Hayne). Revista Brasileira de Plantas Medicinais, Botucatu, v.13, n.1, p.1-7, 2011.

https://www.researchgate.net/publication/277232471_Avaliacao_do_efeito_antifungico_do_oleo_resina_e_do_ oleo_essencial_de_copaiba_Copaifera_multijuga_Hayne

FERES, C. A. O.; TOLEDO, V. P. C. P.; TAGLIATI, C. A.; PIEDADE, J. B.; HERMONT, F.; ROCHA, O. A. A.; GUIMARÃES, T. M. P. D. Evaluation of the immunotoxicological effects of Dimorphandra mollis Benth., Fabaceae, in rats. Revista Brasileira de Farmacognosia, Curitiba, v. 20, n. 4, p. 607-614, 2010. http://dx.doi.org/10.1590/S0102-695X2010000400022

FERREIRA, D. F. Sisvar: Versão 5.1 (Build 72). DEX/UFLA. 2007.

FILIZOLA, B. D. C. Boas práticas de manejo para o extrativismo sustentável da fava d'anta. Brasília: Instituto Sociedade, População e Natureza (ISPN), 2013. 76 p.

GALINDO, E. A. ALVES, E. U.; SILVA, K. B.; BARROZO, L. M.; MOURA, S. S. S. Germinação e vigor de sementes de Crataeva tapia L. em diferentes temperaturas e regimes de luz. Revista Ciência Agronômica, Fortaleza, v. 43, n. 1, p. 138-145, 2012. http://dx.doi.org/10.1590/S1806-66902012000100017

GIULIANO, I. SILVA, T. G. M.; NAPOLEÃO, R.; GUTIÉRREZ, A. H.; SIQUEIRA, C. S. Identificação de fungos em sementes de Dimorphandra mollis e efeito de diferentes tratamentos. Fitopatologia Brasileira, Brasília, v. 30, n. 5, p. 553, 2005. http://agris.fao.org/agris-search/search.do?recordID=XS2005140521

GONÇALVES, A. C. VIEIRA, F. A.; REIS, C. A. F.; CARVALHO, D. Conservação de Dimorphandra mollis Benth. (Fabaceae) baseada na estrutura genética de populações naturais. Revista Árvore, Viçosa, v. 34, n. 1, p. 95-101, 2010. http://dx.doi.org/10.1590/S0100-67622010000100011

LANDIM, L.; COSTA, J. G. M. Dimorphandra gardneriana Tulasne (fava d'anta) - uma abordagem etnobotânica e riscos de extinção. Revista da Biologia, São Paulo, v. 9, n. 1, p. 1-6, 2012. http://www.ib.usp.br/revista/node/131 
LAZAROTTO, M.; MUNIZ, M. F. B.; BELTRAME, R.; SANTOS, A. F.; MEZZOMO, R.; PIVETA, G.; BLUME, E. Qualidade fisiológica e tratamentos de sementes de Cedrela fissilis procedentes do sul do Brasil. Revista Árvore, Viçosa, v. 37, n. 2, p. 201-210, 2013. http://dx.doi.org/10.1590/S0100-67622013000200001

LEITE, R. P.; MEDEIROS, J. G. F.; NASCIMENTO, L. C.; ARAÚJO NETO, A. C.; GOMES, E. C. S.; MALTA, A. O. Qualidade fisiológica de sementes de sabiá (Mimosa caesalpiniaefolia Benth) tratadas com extratos vegetais. Scientia Plena, Aracajú, v. 8, n. 4, p. 1-5, 2012.

https://www.scientiaplena.org.br/sp/article/view/1022

LOBATO, A. K. S. SANTOS, D. G. C.; OLIVEIRA, F. C.; GOUVEA, D. D. S.;TORRES, G. I. O. S.; LIMA JÚNIOR, J. A.; OLIVEIRA NETO, C. F.; SILVA, M. H. L. Ação do óleo essencial de Piper aduncum L. utilizado como fungicida natural no tratamento de semente de Vigna unguiculata (L.) Walp. Revista Brasileira de Biociências, Porto Alegre, v. 5, supl. 2, p. 915-917, 2007.

http://www.ufrgs.br/seerbio/ojs/index.php/rbb/article/view/750

MAGUIRE, J. D. Speed of germination aid in selection and evaluation of seedling emergence and vigor. Crop Science, Madison, v. 2, n. 1, p. 176-177, 1962.

MAIRESSE, L. A. S. Avaliação da bioatividade de extratos de espécies vegetais, enquanto excipientes de aleloquímicos. 2005. 340 f. Tese (Doutorado em Agronomia) - Universidade Federal de Santa Maria, Santa Maria, 2005.

MARTINELLI-SENEME, A. POSSAMAI, E.; SCHUTA, L. R.; VANZOLINI, S. Germinação e sanidade de sementes de Bauhinia variegata. Revista Árvore, Viçosa, v. 30, n. 5, p. 719-724, 2006.

http://dx.doi.org/10.1590/S0100-67622006000500005

MATA, M. F. ARAUJO, E.; NASCIMENTO, L. C.; SOUZA, A. E. F.; VIANA, S. Incidência e controle alternativo de patógenos em sementes de mandacaru (Cereus jamacaru DC, Cactaceae). Revista Brasileira de Biociências, Porto Alegre, v. 7, n. 4, p. 327-334, 2009.

http://www.ufrgs.br/seerbio/ojs/index.php/rbb/article/view/1115

MEDEIROS, J. G. F. ARAUJO NETO, A. C.; MEDEIROS, D. S.; NASCIMENTO, L. C.; ALVES, E. U. Extratos vegetais no controle de patógenos em sementes de Pterogyne nitens Tul. Floresta e Ambiente, Rio de Janeiro, v. 20, n. 3, p. 384-390, 2013a. http://www.scielo.br/scielo.php?pid=S2179-

$80872013000300011 \&$ script $=$ sci_abstract $\&$ tlng $=$ pt

MEDEIROS, J. G. F.; ARAUJO NETO, A. C.; MENEZES, N. P. C.; NASCIMENTO, L. C. Sanidade e germinação de sementes de Clitoria fairchildiana tratadas com extratos de plantas. Pesquisa Florestal Brasileira, Colombo, v. 33, n. 76, p. 403-408, 2013b. http://dx.doi.org/10.4336/2013.pfb.33.76.541

MEDEIROS, J. G. F.; SILVA, B. B.; ARAÚJO NETO, A. C.; NASCIMENTO, L. C. Fungos associados com sementes de flamboyant-mirim (Caesalpinia pulcherrima): incidência, efeito na germinação, transmissão e controle. Pesquisa Florestal Brasileira, Colombo, v. 32, n. 71, p. 303-308, 2012.

ainfo.cnptia.embrapa.br/digital/bitstream/item/74824/1/PFB-fungos.pdf

MENEZES, M.; OLIVEIRA, S. M. A. Fungos fitopatogênicos. Recife: Imprensa Universitária da UFRPE, 1993. $277 \mathrm{p}$.

MONDEGO, J. M.; MELO, P. A. F. R.; PINTO, K.M.S.; NASCIMENTO, L.C.; ALVES, E.U.; BATISTA, J. L. Controle alternativo da microflora de sementes de Pseudobombax marginatum com óleo essencial de copaíba (Copaifera sp.). Bioscience Journal, Uberlândia, v. 30, n. 2, p. 349-355, 2014.

http://www.seer.ufu.br/index.php/biosciencejournal/article/view/18119 
MONTANO, H. G.; SILVA, G. S.; ROCHA, R. C.; JIMENEZ, N. Z. A.; PEREIRA, R. C.; BRIOSO, P. S. T. Phytoplasma in "fava d'anta" tree (Dimorphandra gardneriana) in Brazil. Bulletin of Insectology, Bologna, v. 60, n. 2, p. 147-148, 2007.

NASCIMENTO, W. M. O.; CRUZ, E. D.; MORAES, M.H.D.; MENTEN, J.O.M. et al. Qualidade sanitária e germinação de sementes de Pterogyne nitens Tull. (Leguminosae - Caesalpinioideae). Revista Brasileira de Sementes, Brasília, v. 28, n. 1, p. 149-153, 2006. http://dx.doi.org/10.1590/S0101-31222006000100021

NETTO, D. A. M.; FAIAD, M. G. R. Viabilidade e sanidade de sementes de espécies florestais. Revista Brasileira de Sementes, Brasília, v. 17, n. 1, p. 75-80, 1995. https://www.embrapa.br/busca-de-publicacoes//publicacao/477303/viabilidade-e-sanidade-de-sementes-de-especies-florestais

NUNES, J. D.; NERY, P. S.; FIGUEIREDO, L. S.; COSTA, C. A.; MARTINS, E. R. O extrativismo da fava d'anta (Dimorphandra mollis Benth.) na região do norte de Minas Gerais. Revista Brasileira de Plantas Medicinais, Botucatu, v. 14, n. 2, p. 370-375, 2012. http://dx.doi.org/10.1590/S1516-05722012000200018

OLIVEIRA, C. F.; OLIVEIRA, D. C.; PARISI, J. J. D.; BARBEDO, C. J. . Deterioração de sementes de espécies brasileiras de Eugenia em função da incidência e do controle de fungos. Revista Brasileira de Sementes, Londrina, v. 33, n. 3 p. 520-532, 2011. http://dx.doi.org/10.1590/S0101-31222011000300015

PAULA, M. F. B.; BRAGA, R. F.; MOREIRA, P A.; RODRIGUES, L. A.; PIMENTA, M. A. S.; OLIVEIRA, D. A. Caracterização de acessos de fava d'anta (Dimorphandra mollis Benth.) por meio de marcadores moleculares RAPD. Revista Brasileira de Biociências, Porto Alegre, v. 5, supl. 1, p. 282-284, 2007. http://www.ufrgs.br/seerbio/ojs/index.php/rbb/article/view/308

REBOUÇAS, A.C.M.N.; MATOS, V.P.; FERREIRA, R.L.C.; SENA, L.H.M.; SALES, A.G.F.A.; FERREIRA, E.G.B.S. Métodos para superação da dormência de sementes de quixabeira (Sideroxylon obtusifolium (Roem. \& Schult.) T.D.Penn.). Revista Ciência Florestal, Santa Maria, v.22, n.1, p.183-192, 2012. http://dx.doi.org/10.5902/198050985090

RODRIGUES, J. C. V.; CHILDERS, C. C. Óleos no manejo de pragas e doenças em citros. Laranja, Cordeirópolis, v. 23, n. 1, p. 77-100, 2002.

https://webcache.googleusercontent.com/search?q=cache:xkqBsA02TqcJ:https://www.researchgate.net/profile/ Jose_Rodrigues30/publication/268416019_

SANTOS, F. E. M.; SOBROSA, R. C.; COSTA, I. F. D.; CORDER, M. P. M. Detecção de fungos patogênicos em sementes de acácia-negra (Acacia mearnsii de Wild). Ciência Florestal, Santa Maria, v. 11, n. 1, p. 13-20, 2001. http://dx.doi.org/10.5902/19805098491

SILVA, L. G.; COSMI, F. C.; JESUS JUNIOR, W. C.; SOUZA, A. F.; MORAES, W. B. Efeito do tratamento químico na sanidade de sementes de espécies florestais. Ciência Florestal, Santa Maria, v. 21, n. 3, p. 473-478, 2011. http://dx.doi.org/10.5902/198050983804

SORATO, A. M. C.; SILVA, T. G. M.; PERES, W. M.; MATOS, D. L.; DAVID, G. Q. Controle alternativo de Aspergillus flavus em sementes de Acacia mangium. Cadernos de Agroecologia, [S.1.] v. 11, n. 2, p.1-9, 2016.

http://www.cpao.embrapa.br/cds/agroecol2016/PDF's/Trabalhos/Controle\%20Alternativo\%20de\%20Aspergillu s\%20flavus\%20em\%20Sementes\%20de\%20Acacia\%20mangium.pdf

SOUSA, R. M. S.; SERRA, I. M. R. S.; MELO, T. A. Efeito de óleos essenciais como alternativa no controle de Colletotrichum gloeosporioides, em pimenta. Summa Phytopathol, Botucatu, v. 38, n. 1, p. 42-47, 2012. http://dx.doi.org/10.1590/S0100-54052012000100007 
SOUZA, V. C.; BRUNO, R. L A.; ANDRADE, L. A. Vigor de sementes armazenadas de ipê-amarelo Tabebuia serratifolia (Vahl.) Nich. Revista Árvore, Viçosa, v. 29, n. 6, p. 833-841, 2005. http://dx.doi.org/10.1590/S0100-67622005000600001

STEFFEN, R. B.; ANTONIOLLI, Z. I.; STEFFEN, G. P. K. Efeito estimulante do óleo essencial de eucalipto na germinação e crescimento inicial de mudas de Eucalyptus grandis. Pesquisa Florestal Brasileira, Colombo, v. 30, n. 63, p. 199-206, 2010. http://dx.doi.org/10.4336/2010.pfb.30.63.199

TAKANO, E. H.; BUSSO, C.; GONÇALVES, E. A. L.; CHIERICE, G. O.; CATANZARO GUIMARÃES, S. A.; CASTRO-PRADO, M. A. A. Inibição do desenvolvimento de fungos fitopatogênicos por detergente derivado de óleo da mamona (Ricinus communis). Ciência Rural, Santa Maira, v. 37, n. 5, p. 1235-1240, 2007. http://dx.doi.org/10.1590/S0103-84782007000500003

URSULINO, M. M.; COSTA, M.P.S.D.; MEDEIROS, J.G.F.; ALVES, E.U.; ARAUJO, P.C.; BRUNO, R.L.A.; ARAUJO, L. R. Seed viability of Dimorphandra gardneriana subject to water stress in different temperatures. Ciência Rural, Santa Maria, v. 46, n. 12, p. 2090-2095, 2016. http://dx.doi.org/10.1590/0103$8478 \mathrm{cr} 20120792$

VECHIATO, M. H.; PARISI, J. J. D. Importância da qualidade sanitária de sementes de florestais na produção de mudas. Biológico, São Paulo, v. 75, n. 1, p. 27-32, 2013.

http://www.infobibos.com/Artigos/2010_3/SementesFlorestais/index.htm

ZANANDREA, I.; JULIANO, D. S.; ANDRÉA, B. M.; JULIANE, L.; VERIDIANA, K. B. Atividade do óleo essencial de orégano contra fungos patogênicos do arroz: crescimentos micelial em placas. Revista Brasileira de Farmacognosia, João Pessoa, v. 14, supl. 1, p. 14-16, 2004. http://dx.doi.org/10.1590/S0102-

$695 \times 2004000300006$ 